\title{
The Untold Benefits of Mineral Mining in Developing Countries: A Case Study of Sierra Leone
}

\author{
Moses Fayiah $^{1 \& 2}$, ShiKui Dong ${ }^{* 1}$ Sanjay Singh ${ }^{3}$, Muloma Seibatu Fayiah ${ }^{4}$ \\ ${ }^{I}$ State Key Laboratory of Water Environment Simulation, School of Environment, Beijing Normal University, \\ Beijing, China \\ ${ }^{2}$ Department of Forestry, School of Natural Resources Management, Njala University, Njala, Sierra Leone \\ ${ }^{3}$ Biodiversity and Climate Change Division, Indian Council of Forestry Research and Education, Dehradun, \\ India \\ ${ }^{4}$ School of environmental Sciences, Njala University, Njala Campus, Sierra Leone
}

*Corresponding Author: ShiKui Dong, State Key Laboratory of Water Environment Simulation, School of Environment, Beijing Normal University, Beijing, China

\begin{abstract}
Sierra Leone is endowed with abundant natural resources that have potential to transform the lives of its citizens if sustainably utilized. Although the blueprint of mining in Sierra Leone is characterized by environmental degradation, but the sector also has positive impact on society. Since 1930, mineral extraction incomes have been helping to forge socio-economic development in the small nation although critics argue that the impact is barely felt or seen. Over the years, mineral resources have been the main source of export and direct foreign exchange earning for Sierra Leone. Artisanal and large-scale mining have provided jobs for thousands of people of Sierra Leone over the past decades. Income from mining especially in rural community's support livelihood and regulate the local economy in mining communities. Revenues generated from mining in the form of taxes, exploration fees, environmental impact assessment and monitoring fees, surface rent, license fees and customs taxes among others have help the government in undertaking massive infrastructural development across the country. Mining companies over the years have built schools, clinics, police stations, community centers, bridges, engaged in road maintenance, provide scholarship for outstanding student within the mining communities, support agribusiness ventures, support sporting activities and provided loan to local for business startups as part of their corporate social responsibilities. Nonetheless, improper reporting, corruption, civil war, weak mining policies, inadequate reporting of revenue collected from and lack of transparency prompted public mistrust on benefits of mining in Sierra Leone. It is recommended that revenue generated by mining companies be made public and corporate social responsibilities (CSR) undertaken be published regularly.
\end{abstract}

Keywords: Mineral extraction, Sierra Leone, Mining companies, mineral mining, corporate social responsibility

\section{INTRODUCTION}

Sierra Leone is among the mineral rich third world countries in the world and has an area of 71, 874 sq. $\mathrm{km}$. The country is a member of the Economic Community of West African States (ECOWAS), the African Union, the Mano River Union among other organizations in Africa (Alix, 2015). The country is bordered to the north, northeast by Guinea, bordered to the south east by Liberia and bordered to the west by the Atlantic Ocean (Sierra Leone Investor Guide 2019). The country practices democracy as the rule of law and has a population of about 7 million people. Mineral extraction remains Sierra Leone's most lucrative source of foreign income, employment, export and livelihood booster (Chimange, 2015). The mining sector is the second largest supporter of Sierra Leone's economy after agriculture. Furthermore, it accounts for the country's major export earnings, government source of earning, and foreign exchange (Alix, 2015). The country is rich in minerals such as; diamonds, rutile, gold, platinum, Iron ore, bauxite, gas, among others (Wilson, 2015; Fayiah et al., 2018; Maconachie, 2018; Alix, 2015; Fayiah et al., 2020). Basically, the mining sector in Sierra Leone is made up of three sub-sectors; 1) large scale precious mineral production; 2) large-scale nonprecious mineral production; 3 ) and precious mineral production via artisanal and small-scale mining 
(Arai et al., 2010; GoSL, 2008; ILO, 2008).In 1996, Sierra Leone was ranked 19th and scored 77.5 in the mining contribution index (MCI) whereas in 2016, it was ranked 15th and scored 87.1 (MCI) respectively (Ericsson and Lof, 2019). In as much as mineral extraction is considered the main culprit of environmental degradation; yet it has made some significant sustainable contribution to the socioeconomic fabric of Sierra Leone over time. Jalloh et al. (2013) speculated that the mining industry has the potential of becoming the engine of economic boom and infrastructural development in Sierra Leone if its resources are sustainably utilized. Additionally, the country has good prospect of discovering more mineral deposit based on the fact that the country is still largely unexplored (Anyanwu, 2011). This case study is poised to give an insight on the positive contribution of mineral extraction to the economic and social development of Sierra Leone. The names of major mining companies operating in Sierra Leone over the past decade are listed in (Table 1). Companies like Sierra Rutile Ltd and Koidu Holding has however been mining in Sierra Leone for the past two decades.

Table1. Name of major mining companies previously or currently mining in Sierra Leone over the past decade

\begin{tabular}{|l|l|l|l|l|}
\hline & Name of Mining Company & Minerals & Lease date & Comments \\
\hline 1 & African Minerals Ltd Group of Companies & Iron ore & $6 / 8 / 2010$ & On hold. Sold to Shandong \\
\hline 2 & London Mining Company Ltd dated & Iron ore & $27 / 02 / 2012$ & Closed \\
\hline 3 & Koidu Holdings S.A & Diamonds & 2010 & Ongoing \\
\hline 4 & Sierra Minerals Holdings1 Limited & Bauxite & $16 / 07 / 2012$ & Ongoing \\
\hline 5 & Tonguma Limited Sierra Leone & Diamonds & $10 / 07 / 2012$ & Ongoing \\
\hline 6 & Sierramin Bauxite Limited & Bauxite & $5 / 12 / 2017$ & Ongoing \\
\hline 7 & Sierra Leone Mining Limited & Iron ore & $5 / 12 / 2017$ & License Cancel \\
\hline 8 & Marampa Iron Ore Limited & Iron ore & $05 / 2014$ & License Cancel \\
\hline 9 & Sierra Rutile & Rutile & & Ongoing \\
\hline
\end{tabular}

\subsection{Objective and Structure of the Article}

This article is poised to critically highlight the positive socio-economic contributions of mineral mining in Sierra Leone. The article talks about; 1) accessing the contribution of mining operations in Sierra Leone; 2) CSR (Corporate Social Responsibility) undertaken by mining companies; 3) job creation and livelihood contribution of mineral mining in Sierra Leone over the past decades. It is organized as; section 1 giving a brief background about Sierra Leone, Section 2 summarizing literatures relevant to the study; section 3 presenting study method, section 4 present results and discussion and section 5 presents conclusion and recommendation.

\section{REVIEW OF SOME RELEVANT LITERATURES}

A recent study published by Ericsson and Lof, (2019) examined the contribution of mining activities to national economies from 1996 to 2016. The authors concluded that mining makes a significant contribution to the over all economic development of nations like Sierra Leone over the years. Jalloh et al. (2013) investigated the different mineral resources endowment, their geology and their potential in developing Sierra Leone. They concluded that mineral resources if used judiciously will contribute greatly to the sustainable development of Sierra Leone (Jalloh et al., 2013). Mansaray, (2020) cross examined sustainable development and it linked to corporate social responsibility of multinational mining companies across Sierra Leone. The author highlighted some of the contributions made by mining companies in honoring their corporate social responsibilities in Sierra Leone. The author listed scholarship provision, job creation, agribusiness support, construction of clinics, schools, housing, maintenance of feeder roads among others as some of the corporate social responsibility undertaken by companies operating in Sierra Leone. The role played by CSR in supporting businesses towards sustainable development transparency and accountability within the context of Sierra Leone was probed by (Jackson and Jackson, 2016). They resolved that; activities undertaken by Miro-Forestry Company and Sierra Rutile Limited exhibit good attributes in contributing to the sustainable development of Sierra Leone. M' cleod, (2012) assessed iron ore production and sustainable development effects in Sierra Leone over the next fifty-year period. Wilson, (2015) investigated corporate social responsibility in connection to power relation and obstructions to community development in Sierra Leone. However, the authors resolved that corporate social responsibility has had minimal impact on community development in mining areas. Similarly, Fayiah, (2020) examined the environmental damages caused by mining companies and concluded that mining is causing more harm than good to communities in which they operate. Akiwumi, (2014) investigated the cultural 
heritage and sustainable development encounters in the context of strangers and their mining roles in Sierra Leone. The author concluded that the presence of strangers across mining areas in Sierra Leone has become a deep rooted and worsen problem in mining communities and that is due to power imbalance entrenched in our constitution (Akiwumi, 2014). Similarly, Brima (2004) cautioned that the influx of immigrant in mining communities results in the escalation of prostitution, crimes and drugs abuse.

Although mining operation blueprint in Sierra Leone has been deemed environmentally unsustainable, yet there are positive landmarks of mining in Sierra Leone. Many scholars concentrate on the negative aspect of mining in Sierra Leone (Fayiah, 2020), but very little information or attention is given to the various contributions of mining proceeds to the sustainable and economic development of Sierra Leone. This gap in information has made the public in Sierra Leone to frown at mining operations in their localities and sometimes stage protest to resist their operations.

\section{Methodology}

\subsection{Study Area}

The study concentrated on a small country located in West Africa called Sierra Leone. Sierra Leone is a tropical nation bordered by Guinea and Liberia (Statistic Sierra Leone, 2017). The country is richly endowed with natural resources including diamonds, bauxites, gold, iron ore, rutile, ilmenite etc. The population of the country currently stands at 7 million people according to the 2015 estimates (Statistics Sierra Leone, 2015).This case study made use of relevant information from contemporary published and unpublished secondary data sources from government reports, articles, workshop, and conference proceedings among others. The authors carefully reviewed government mineral revenue and company's social responsibilities policies and reports spanning from colonial and post independent periods.

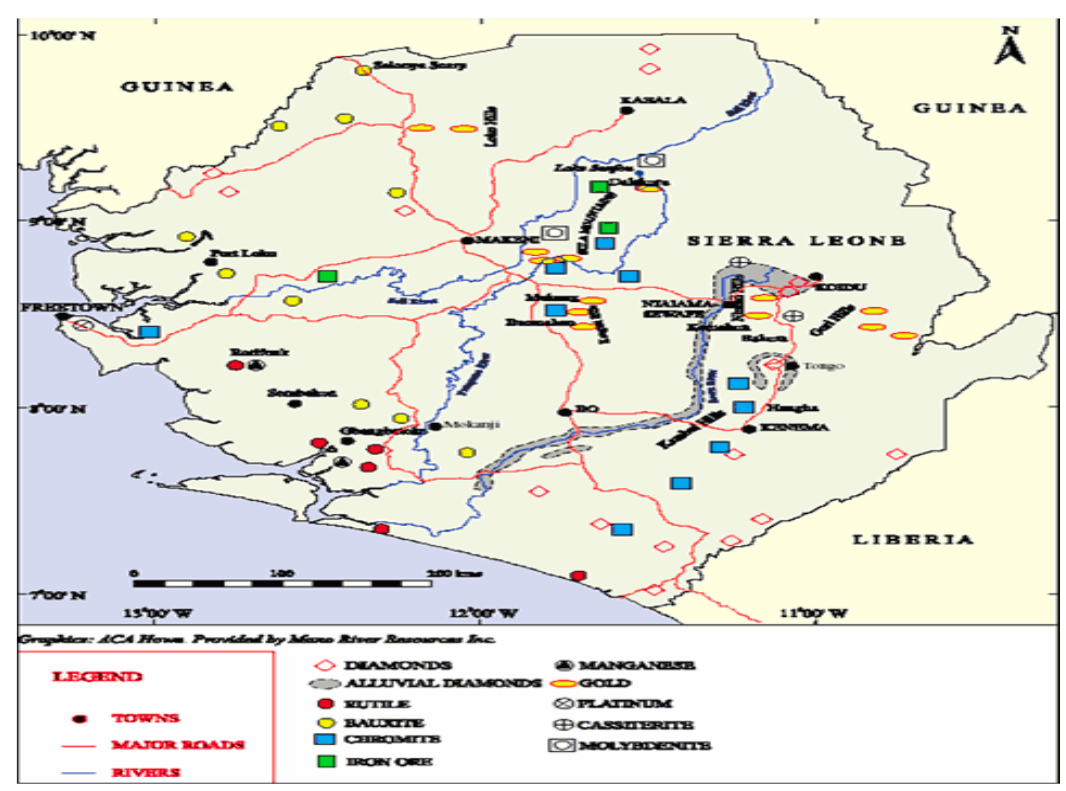

Figure1. Map of Sierra Leone showing mineral distribution. (Source: Sierra Leone Investment and Export Promotion Agency)

\section{RESULTS AND DisCUSSIONS}

\subsection{Mining Based Employment}

Mining based business has been the biggest employer after government and agriculture in Sierra Leone. By 1956, around 75, 000 excavators were lawfully or illegally occupied with mining activity in Sierra Leone (Fanthorpe and Gabelle. 2013). However, by 1975, the nation announced a drop to 3,700 legally employed mines laborers and 20,000 to 30, 000 illegal mines laborers for the most part occupied with high quality mining of diamonds in the nation (Swindell, 1975). Nonetheless, other mining companies extracting minerals other than diamonds employed around 200 to 1,200 labor force within the same period of time (Swindell, 1975) and by 2006, it was estimated by government that around 40,000 artisanal miners were involved in either legal or illegal diamond mining in Sierra Leone (Licthe, 2014; Ministry of Mineral Resources, 2010). The mining sector boom in the early 
1990ssaw an increase of around 250,000 workers surviving solely on mining activities in Sierra Leone (Victoria, 2007). However, the civil war disrupted mining progress in Sierra Leone; leaving only the fighting factions in mining diamonds with the help of captured labor force thereby decreasing mining base employs to few hundreds. When the war finally ended in 2003, it took the country over five years to attract credible investors into the mining sector again. By 2009, 989 Sierra Leonean were legally employed in the mines sector and by 2013, the figure rose to 9, 174 legal mines workers in the country (Statistics Sierra Leone, 2013). However, an estimate by Diamond Development Initiative, (2011) put the figures of artisanal miners in Sierra Leone to 120,000 within the same period. Based on the country employment rate report, by 2013, the mining sector accounted for about $7 \%$ of employment of Sierra Leoneans. From 2013 to 2014, the wage employment percentage by mining and other extraction industries in Sierra Leone was $48.8 \%$ of the country total wage employment survey (Statistics Sierra Leone and World Bank, 2014). As of 2015, Sierra Leone had 82,255 people working in mining and quarrying sector (SLEITI, 2018). However, a recent report published by the CIA World Fact book, (2020) estimated that; $61.1 \%$ of the population is engaged in agricultural employment (subsistence and commercial), 33.4\% are employed in the service sector while 5.5\% are employed in the mining sector. This drop-in employment ratio may be due to the fall in the global iron ore price and the Ebola crisis that ravaged Sierra Leone from 2014 to 2016. Although only 7\% of the total employment in 2012 and 2013 was attached to the mining sector, yet the mining job is among highest paid job in Sierra Leone (Margolis et al., 2016; Statistics Sierra Leone, 2014).

\subsection{Mining as the Major Source of Export for Sierra Leone over the Years}

Currently, Sierra Leone is ranked $152^{\text {nd }}$ aslargest exporting economy globally and as at 2017 , the export value was US\$ 839 million (OEC, 2020). Mining is the backbone and primary export sector of Sierra Leone's economy and provide majority of foreign earning. In particular, mineral exporting in Sierra Leone peaked from 2011 to 2013 giving the country a double-digit growth and boosting the economy significantly. Before the closure of Rutile and bauxite companies in 1995, mining was contributing approximately $20 \%$ of the gross domestic product of Sierra Leone (Global Security of Sierra Leone Economy, 2020). The country heavily relies on the mining sector for revenue, employment, export and foreign exchange. This complete reliance on digging for trade nonetheless, renders Sierra Leone vulnerable to any shift in global mineral prices as seen in 2011 (SLEDAT, 2020). About $60-70 \%$ of mineral export from Sierra Leone is from diamond, iron ore, rutile and bauxite (Economic Commission of Africa, 2017).Between 2013 and 2014 alone Sierra Leone exported over 100 million dollars worth of mineral (SLEDAT, 2020). In 2015 and 2016, artisanal gold mining revenue was worth 3.6 and 4.3 million dollars while artisanal diamond mining contributed to $36.33 \%$ of 2014 mineral export (SLEITI, 2018). Among numerous ways, mining activities adds to the economy of Sierra Leone are through surface rent, mining license, environmental impact assessment and monitoring fees, community development fund, taxes etc. According to (figure 1), mineral resources could be the major source of export as compared to cocoa and fish. This is a clear indication of the contribution of mining in earning foreign exchange for Sierra Leone.

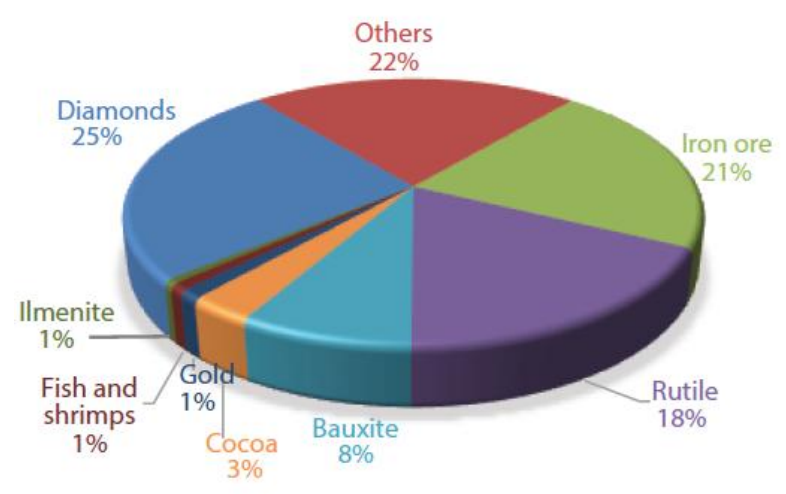

Figure1. Composition of total export of Sierra Leone for 2016. (Source: Economic Commission of Africa, 2017; Bank of Sierra Leone 2017)

From 2010 to 2017, Sierra Leone has reported to export more than 4 million carat of diamond (mining journal, 2018). In 2011, the importation of machinery and transport equipment because of bauxite mining boom reach a record of about USS $\$ 190$ million thereby attracting huge customs wage bill for clearance (Directorate of Science, Technology and Innovation of Sierra Leone, 2020). 

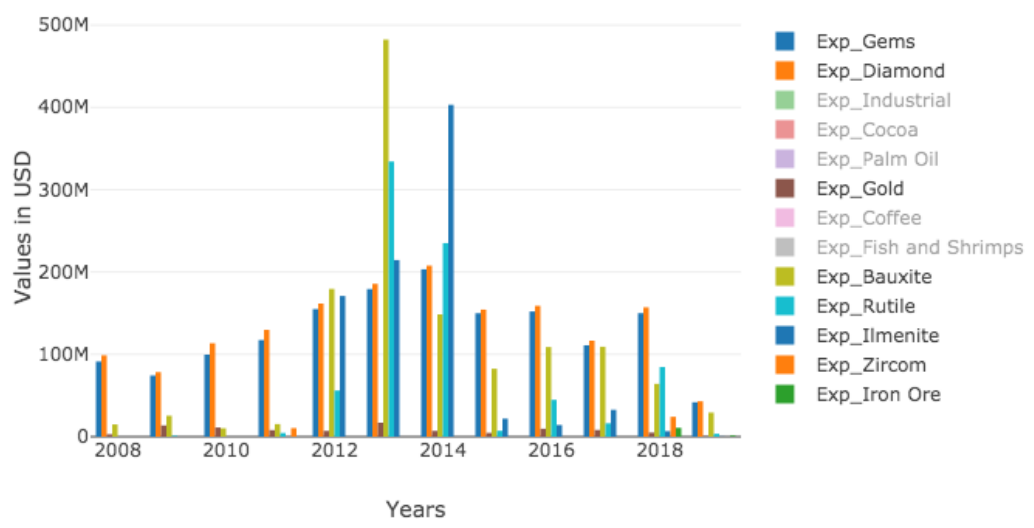

Source: (SLEDAT, 2020)

Table1. Mineral sector contribution to export and GDP in \$ (Statistics Sierra Leone 2017; Sierra Leone Economy 2020;Anyanwu, 2011; Bank of Sierra Leone, 2017c)

\begin{tabular}{|l|l|l|l|l|l|l|l|l|l|l|}
\hline Years & $\mathbf{2 0 0 9}$ & $\mathbf{2 0 1 0}$ & $\mathbf{2 0 1 1}$ & $\mathbf{2 0 1 2}$ & $\mathbf{2 0 1 3}$ & $\mathbf{2 0 1 4}$ & $\mathbf{2 0 1 5}$ & $\mathbf{2 0 1 6}$ & $\mathbf{2 0 1 7}$ & $\mathbf{2 0 1 8}$ \\
\hline Mining & 7.0 & 4.2 & 8.2 & 15.2 & 28.5 & 4.6 & 1.9 & 2.6 & 0.5 & 0.7 \\
\hline Export & 68.0 & 56.0 & 90.0 & 85.0 & 90.0 & 90.0 & 75.0 & 91.1 & 80.0 & 85.0 \\
\hline
\end{tabular}

The contribution of the mineral sector to the gross domestic product (GDP) of Sierra Leone is uncertainty (Table 1). The highest contribution of the sector to the national budget was in 2013 (28.5) during the iron ore boom period.

\subsection{Artisanal Mining as a Source of Income and Job Security}

By 2017, it was estimated that about 40.5 million people were engaged in artisanal mining globally (Fritx et al., 2018).Across Africa, artisanal mining is considered the quickest way of getting nonskilled employment for youth without formal education. In Sierra Leone for instance, it is estimated that over 300,000 un-skilled workers and their families are engaged in artisanal mining in different part of the country (GOSL, 2018; Swindell, 1975).High-quality mining artisanal has been portrayed as a basic driver of prosperity in Sierra Leone (Licthe, 2014) while it also been considered the route out of poverty because of it socio-economical prospects in Sierra Leone (GOSL, 2018). Since artisanal mining in Sierra Leone attracts many young people from different parts of the country, its positive implication spreads right across the country with great prospect of improving the economic, social and livelihood of miners relatives across the country (Licthe, 2014). These attributes have made artisanal mining in Sierra Leone an influential force of economic growth. By 2013, artisanal mining sector accounted for $38 \%$ of diamond exported from Sierra Leone. With majority of the youth population in Sierra Leone unemployed; artisanal mining has helped tackle some aspect of this situation by providing jobs and source of income for some idle youths. Artisanal mining has greatly enhanced livelihood opportunities for thousands of Sierra Leoneans (GOSL, 2018). Due to artisanal mining, local economies in mining edge communities across the country are better off compared to other communities. It is estimated that around $10 \%$ of Sierra Leonean are impacted from artisanal mining resources and revenues directly or indirectly (GOSL, 2018).

\subsection{Corporate Social Responsibility of Mining Companies and it Impact on Socio-Economic Livelihood on Mining Communities}

Mineral extraction has contributed substantially to the economic growth of Sierra Leone since its independence in 1961 (UNEP, 2010; Licthe, 2014; Wilson, 2015). CSR looks at mutual societal and corporation's relationship in terms of social and environmental benefits in mining communities (Crowther and Aras, 2008). Although critics argue that mining companies in Sierra Leone have not lived to the expectation in term of CSR; yet some positive strides and landmarks have been made in some mining communities (Mansaray, 2020; SLEITI, 2017). Those communities where mineral extraction is ongoing consider these processes as the principal source of livelihood in exchange for the minerals extracted (Jackson and Jackson, 2016; Jackson, 2015b). Some companies like Sierra Rutile and Koidu holdings Ltd have displayed positive evidence of CSR while mining in Sierra Leone base on emerging evidence of some development projects that are benefiting indigenes of these 
communities (SRL, 2018; Mansaray, 2020). For instance, during the Ebola outbreak in Sierra Leone, Sierra Rutile donated 487,000 USD to fight the disease and keep the community healthy (SRL, 2014a; 2014b; Jackson and Jackson, 2016). Other companies have built markets, community centers, schools, clinics, pave feeder roads, gave scholarships to students (Awoko, 2013) and support various sporting and other social activities in mining edge communities (Mansaray, 2020; SRL, 2014a; 2014b; Jackson, 2015; Wilson, 2015; Nwagbara and Kamara 2015; Jackson and Jackson, 2016). Another positive note related to CSR of companies is the establishment of fish ponds, support to agribusinesses and the planting trees in abandon mine areas from mineral revenue (Samba, 2012; Mansaray, 2020; SRL, 2014). A recent study by Mansaray, (2020) found that the three multinational companies in Sierra Leone are implementing their CSR in one way of the other. However, the extentto which they are implementing their CSR is debatable. It is likely to be seen that, residents agree to these companies and indeed honor their CSR through developmental projects undertakings (Mansaray, 2020). CSR task has forced companies to contribute to the socio-economic development of local communities through infrastructural development. Besides jobs and other revenues provided by mining companies, friendly ties with stakeholders and their communities are said to have improved over the years(SRL,2018; Nwagbara and Kamara 2015). Community learning institutions like the Jackson and Devon Anderson Technical Institute and the Ruby Rose Education and Recreational Centre are being co-sponsored by Sierra Rutile to support adult learning and other trades for adult without formal education (SRL, 2018).
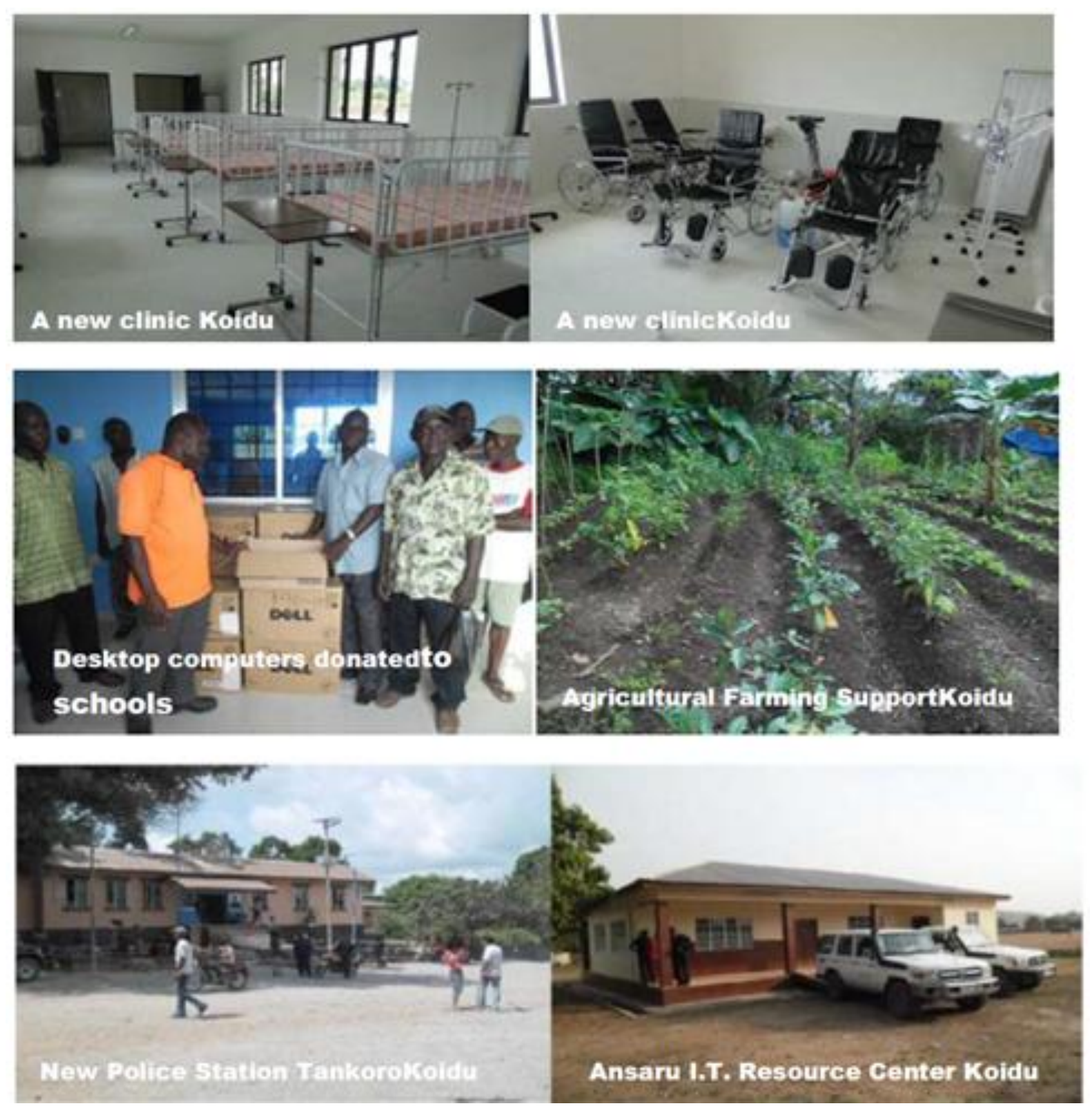


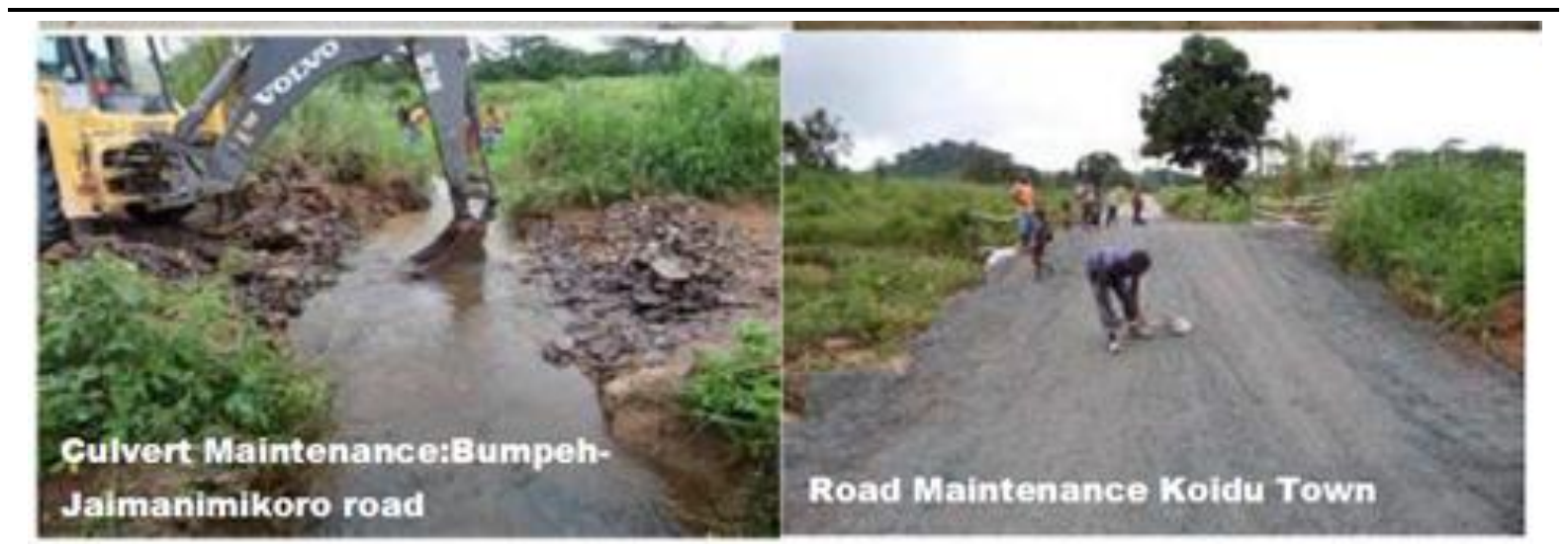

Figure1. Corporate Social Responsibility of Octea Ltd TankoroKono, mining company

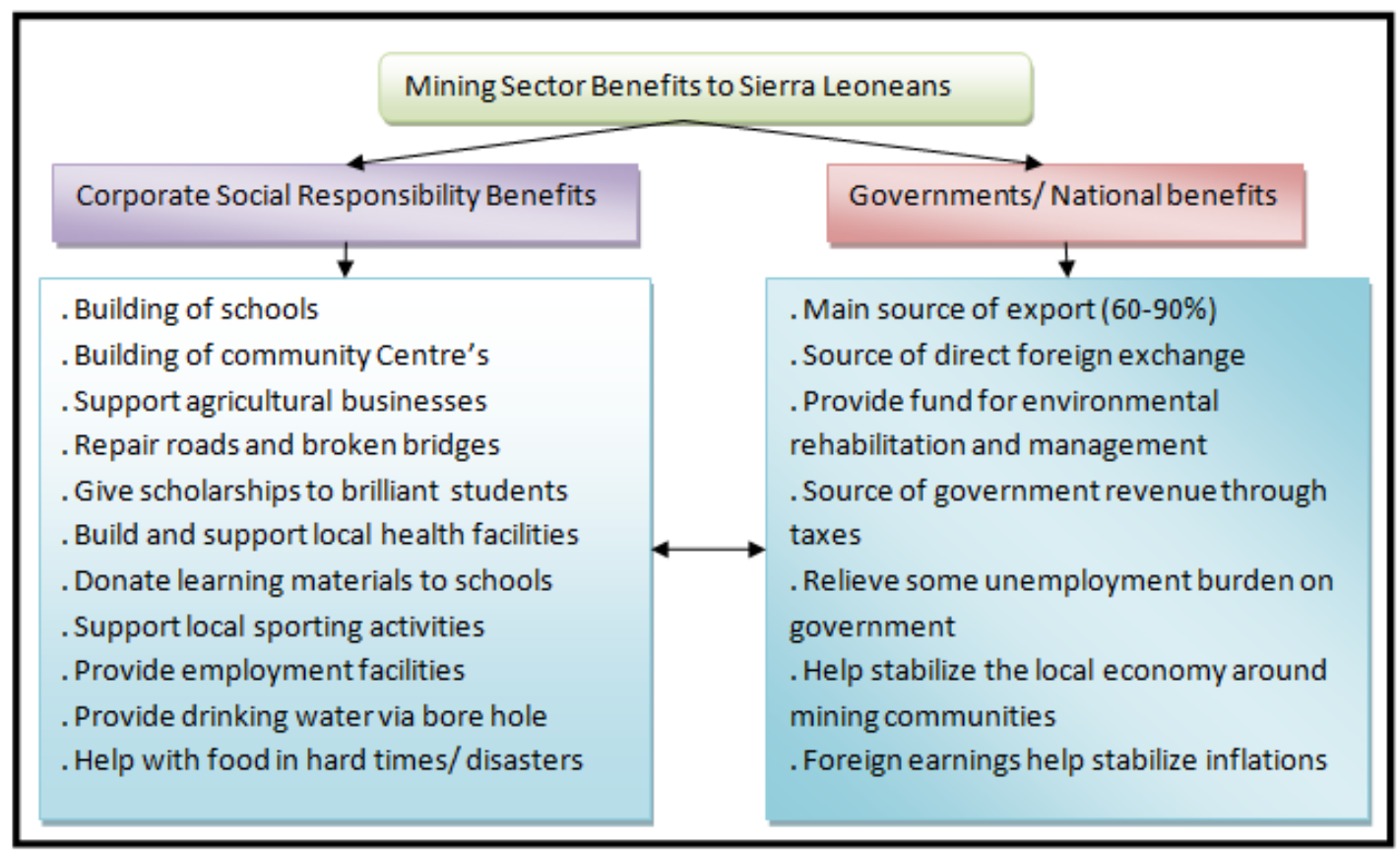

Figure2. Mining sector benefits to Sierra Leonean through corporate social responsibility and taxes

\subsection{Mineral Extraction Contribution to Sierra Leone's Economy}

The mining sectors have over the years played a prominent role in terms of GDP growth, export and direct foreign investment in Sierra Leone (SLEDAT, 2020; SLEITI, 2015; 2016; 2017).Over the years, mineral extraction has aided the economy of Sierra Leone in the form of royalties, taxes, surface rent, license fees, customs charges, government community fund, and environmental protection agency support among other benefits. Since 1930, mineral extraction income has been used to support the national development of the country as well as putting the Sierra Leone on the limelight for a number of big diamonds discovered. In 1972 a star diamond of Sierra Leone weighing 968.9 carat was found in Kono District. This diamond placed Sierra Leone on the mineral rich countries spot light as it was only third to the first and biggest gem 3, 106 carat diamond found in South Africa in 1905 (Nyaungwa, 2017). In 2017, another 709 carat diamond also found in Sierra Leone was among the 20 biggest diamonds ever found globally (BBC News, 2017). The original plan after the sale of this 709 carat diamond (7.7 million \$) was to provide electricity, medical facility, clean drinking water, construct road, bridges in the town where the diamond was found.

Sierra Leone possesses one of the largest rutile deposits globally with abundant reserves of diamonds and iron ore. The huge deposits of these minerals contribute to the gross domestic products of the country. For example, between 2011 and 2013, iron ore mining was the major driving force for the rapid economic growth Sierra Leone experienced and contributed 18\% Gross Domestic Product by the end of 2013 (Economic Commission for Africa, 2017; Statistics Sierra Leone 2017). In 2016 for example, mining proceedings from bauxite, rutile, gold, iron ore, diamonds, and ilmenite accounted for 5.8\% of the total GDP of Sierra Leone (Economic Commission for Africa, 2017; Statistics Sierra 
Leone 2017; SLEITI, 2017).According to the recent mining contribution index (MCI) calculated by Ericsson \&Löf, (2019), Sierra Leone is ranked $16^{\text {th }}$ in the first 20 countries with high MCI globally. The country has moved from $19^{\text {th }}$ position in 1996 to $16^{\text {th }}$ position in 2019 placing it among the top 20 countries where mining contributes greatly to the economic development of the country (Ericsson \&Löf, 2019).However, the country's growth performance is volatile and uncertain due to price fluctuation of mineral resources like iron in global market observed in recent years (Economic Commission for Africa, 2017). It is estimated that about 250,000 people across Sierra Leone get their livelihood from mining and quarrying operations because it employs roughly $14 \%$ of the labor force (Jalloah et al., 2013). As of 2017, around US\$ 52million was paid to the National Revenue Authority (NRA) of Sierra Leone by four large scale mining companies operating in the country (Mining journal, 2018). Figure (2) describes the criteria and contribution of mining in Sierra Leone. The artisanal mining is labor intensive with no prior experience in mining needed. However, small and large scale mining requires prior experience and qualification for certain roles (Fig. 1). In terms of contribution, all categories of mining contribute to the economy and livelihood although the large scale mining lead in revenue generation.

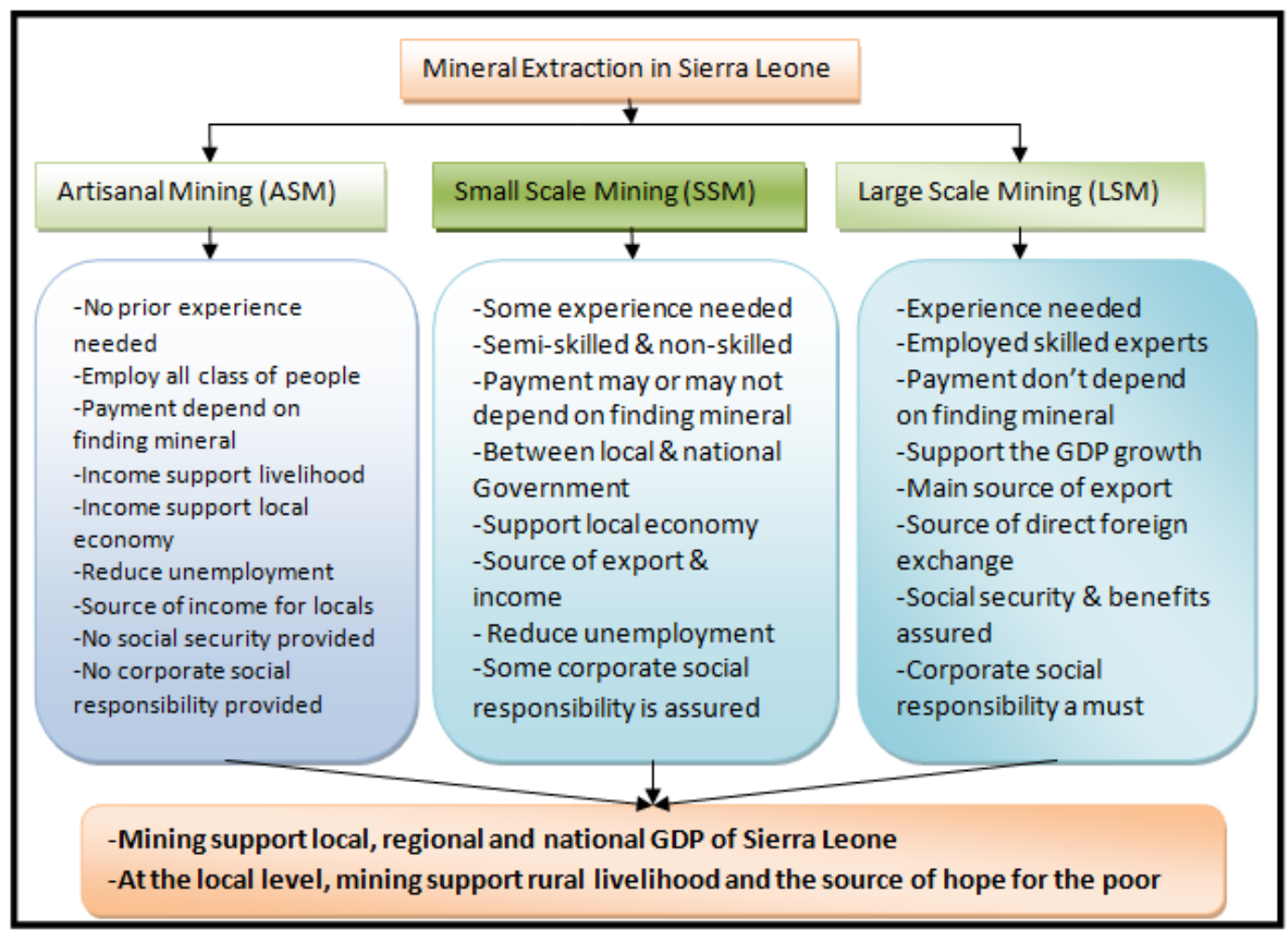

Figure1. Flow chart showing the category, criteria and contribution of the mining sector in Sierra Leone

\section{CONCLUSION}

Dynamic mineral extraction in Sierra Leone started around 1930 and has since been contributing to the economic growth of the country. The contribution of mineral resources to the socio-economic expansion of Sierra Leone has been great. Since mining started in Sierra Leone, surface rent, government taxes, license fees, exploration fees, environmental impact assessment and monitoring fees, agricultural development fund, royalties, customs charges among other benefits have been honored by every mining company operating in Sierra Leone. However, corruption, civil war, weak mining policies and the lack of transparency by governing authorities over the years has made the local and the international community termed the endowment and its related instability as a "resource curse". Corporate social responsibilities in the form of building community centers, schools, clinics, support to agricultural activities, provision of scholarships, support to community sporting etc. have been undertaken by majority of the companies operating in Sierra Leone. Mining companies have been engaged in many community development projects and have provided jobs for indigenes hence supporting rural livelihood. Proceedings from mining companies have transformed the lives of many people and have made some rich and prosperous. Revenue collected in the form of tax from mining companies has played a critical role in supporting government development projects across the country over time. With the ongoing reforms in regard to mineral extraction in Sierra Leone together 
with stronger governance; mining has the potential to promote massive economic development and alleviate mining communities from abject poverty over the next decade. It is the author's view that mineral extraction income and CSR of mining companies undertakings are under reported and nontransparent to the public. This gap in information has created trade-off and lack of trust from the public and the international community. Going forward, revenue generated from companies should be made public and community development projects should be transparent and inclusive. Safety within the mining environments in Sierra Leone should be ensured and prioritized. To achieve sustainable mining and economic development in Sierra Leone;a management framework will be essential for human capital development, economic growth, better governance, infrastructural development and sectorial linkages.

\section{REFERENCES}

Akiwumi, A. F. (2014). Strangers and Sierra Leone mining: cultural heritage and sustainable development challenges. Journal of Cleaner Production. 84, 773-782.

Anyanwu, J.C. (2011). Mining And The Economy Of Sierra Leone Conference: 4th West \& Central Africa Mining Summit, Accra International Conference Centre, Accra, Ghana. 26th - 27th September 2011.

Alix, Y. (2015). Mining in Sierra Leone: an Overview of the Current Legal Framework. Herbert Smith Freehills LLP. Australia, Brisbane, Melbourne, Perth, Sydney 20 May 2015.

Arai, Y., Cissé, A., Sock, M. (2010). Promoting job creation for young people in multinational enterprises and their supply chains: Sierra Leone/International Labour Office. - Geneva: ILO, Employment Sector Employment Report No. 8; Pp59.

Awoko, (2013). 25 Kono Students Receive Scholarships from Koidu Holdings. http://awoko.org/2012/06/15/25kono-students-receive-scholarships-from-koiduholdings/(accessed 14.05.2020).

Bank of Sierra Leone (2017a) Current Account Balance (unpublished)

Bank of Sierra Leone (2017b) Financial Account Balance (unpublished).

Bank of Sierra Leone (2017c). Trade data (unpublished). Available from https://www.bsl.gov.sl/External_Sect o_Data.html.(Accessed 14 May 2020).

BBC, News Africa. (2017). Sierra Leone pastor finds huge diamond in Kono. BBC News March 17, 2017. https://www.bbc.com/news/world-africa-39289749 (accessed April 2020).

BSGR and Octea Limited - CSR Initiatives- April 2015, BSG Resources Octéa Limited Corporate Social Responsibility April 2015 https://www.koiduholdings.com/bsgr-and-octea-limited-csr-initiatiives-april201.php

Brima, A. A. (2004). Development Diamonds - Sierra Leone. Paper presented at the Environment, Development and Sustainable Peace: Finding Paths to Environmental Peacemaking Wilton Park Conference, London, UK.

Chimange, A. (2015). Landless - Impacts of mining on the environment and local population. The case of Lunsar and Bumbuna in Sierra Leone. University ofMakeni, Sierra Leone Pp 1-16.

Crowther, D., Aras, G., 2008. Corporate Social Responsibility.Ventus Publishing ApS. Available at:http:// mdos.si/Files/defining-corporate-social-responsibility.pdf

Diamond Development Initiative (2011). The Issues: A large number of actors. https://www.africaportal.org/ documents/607/Background_Paper_on_Micro_Development_Issues.pdf

Economic Commission for Africa -United Nations (2017) Country Profile Sierra Leone. Available at: www.uneca.org/publications. Accessed on March, 2020.

Ericsson, M and Lof O. (2019).Mining's contribution to national economies between 1996 and 2016. Mineral Economics. 32:223-250.

Ericsson, M., \&Löf, O. (2019).Mining's contribution to national economies between 1996 and 2016. Mineral Economics, 32(2), 223-250

Fanthorpe, R and Gabelle.C. (2013).Political economy of extractives governance in Sierra Leone. The World Bank, Washington DC 20433.

Fayiah, M. (2020). Mining and Environmental Degradation: a Gift Brings Grief Scenario for Mining Communities in Sierra Leone. Journal of mining and environment.

Fayiah. M, Otesile A. A and Mattia. S. B. (2018). Review of Challenges Confronting the Implementation and Enforcement of Environmental Policies and Regulations in Sierra Leone. International Journal of Advance Research, 6(6), 530-541.

Federico, Victoria (2007). The Curse of Natural Resources and Human Development. L-SAW: Lehigh Student Award Winners. Archived from the original on 2012-03-22. 
Fritz, M., McQuilken, J., Collins, N., Weldegiorgis, F.(2017). Intergovernmental Forum on Mining, Minerals, Metals and Sustainable Development (IGF). (2017). Global Trends in Artisanal and Small-Scale Mining (ASM): A review of key numbers and issues. Winnipeg: IISD.

Global Security, (2020) Sierra Leone - Mining. Online at www.globalsecurity.org/military/world/africa/slmining.htm

Government of Sierra Leone (2008). Second Poverty Reduction Strategy Paper (PRSP-II) An Agenda for Change, Freetown, Sierra Leone.

International Labour Office (2008). MNE Development and decent work: New directions for multinational enterprises in shaping a fair globalization, Geneva

Jackson, E. A. (2015a). FLEGT Mandate: Its applicability and effectiveness in Sierra Leone. Journal of Applied Thoughts, Ghana.

Jackson, E. A. (2015b). Ethnographic Narrative of Forest Decline in the Goderich Community: The People's Perspectives. Forest Resources 4:157.

Jackson, E.A and Jackson, H.F (2016).The Role of Corporate Social Responsibility in Improving Firms' Business in the Directions of Sustainable Development, Accountability and Transparency. Economic Insights - Trends and Challenges 5; 39-50

Jalloh, A. B., K. Sasaki, M.O. Thomas and Y. Jalloh (2013).The geology, mineral resources of Sierra Leone and how the resources can be used to develop the nation. Procedia Earth and Planetary Science, 6, 131138.

James, M., Manty-Jones, Y.M., and Sengeh, D. (2020). A Report: Sierra Leone Economic Data Analytics Tool; Directorate of Science, Technology, and Innovation in collaboration with Statistics Sierra Leone, Bank of Sierra Leone, and Ministry of Finance Sierra Leone. www.edat.dsti.gov.sl

M'cleod, H (2012). Sustainable development and iron ore production in Sierra Leone: The next fifty years"', in O Johnson (ed.), Economic Challenges and Policy Issues in Early 21st Century Sierra Leone, London: International Growth Centre

Maconachie, R. (2018). How the wealth from Sierra Leone's diamonds fails to enrich local communities. (Accessed 2 February 2020) Online: https://theconversation.com/how-the-wealth-from-sierra-leonesdiamonds-fails-to-enrich-local-communities-96365 (Accessed 0202-2020)

Mansaray H.E. (2019) The Impact of Mining in the Local Communities in Sierra Leone. LAP Lambert Academic Publishing.

Mansaray, H. E. (2020). Corporate Social Responsibility and Sustainable Development : A Case Study of Multinational Mining Companies in Sierra Leone. Budapest International Research and Critics Institute-Journal (BIRCI-Journal) 3, 1 2020, 644-656.

Margolis, D., N. Rosas, A. Turay and S. Turay (2016).Findings from the 2014 Labor Force Survey in Sierra Leone.The World Bank.Available from http://elibrary.worldbank.org/doi/ book/10.1596/978-1-46480742-8.(Accessed 14 May 2020).

Mining Journal, (2018). Sierra Leone, Promise to prosperity (September, 2018). https://www.mining journal. com/digital_assets/469c0ca1-38de-43bd-af37-a4d5cf503844/Sierra_Leone_2018scr_v2.pdf.

Ministry of Mines \& Mineral Resources (MMR). 2010. An overview of the Sierra Leone Minerals Sector: Facts in Brief. Freetown: Government of Sierra Leone. Accessed March 11, 2020.www.slminerals.org/ content/index.php?option=com_content\&view=article\&id=4\&I

Ministry of Mines and Mineral Resources, Government of Sierra Leone, An Overview of the Mineral Sector in Sierra Leone, http://www.slminerals.org (2011

Nwagbara U. and Kamara H.Y. (2015). Corporate Social Responsibility (CSR) Leadership and Poverty Reduction: The Case of Nigeria and Sierra Leone. Economic Insights - Trends and Challenges Vol.IV(LXVII) No. 2/2015

Nyaungwa, M. (2017) World's five largest diamonds.BBC News Africa. https://www.bbc.com/news/worldafrica-39289749

OEC, (2020) Observatory of Economic Complexity. Sierra Leone (SLE) Exports, Imports, and Trade Partners OEC . https://oec.world/en/profile/country/sle/ (Accessed April 2020).

Samba, A., Jan 16, 2012. In Sierra Leone, London Mining Rescues Central Business District of Lunsar. Awareness Times. Available at: http://news.sl/drwebsite/publish/article_200519495.shtml (Accessed 14.05.2020).

Sierra Leone Investor guide (2019). A Private Sector Perspective on the Investment Landscape. Online at http://www.sliepa.org/map-known-mineral-deposits;www.investinginsierraleone.com.(Accessed14 May, 2020). 
Sierra Leone Economy (2020). CIA World Factbook and other Sources https://theodora.com/wfbcurrent/ sierra_leone/sierra_leone_economy.html (Accessed 14.May 2020)

SRL, (2014a) Sierra RutileLtd . Financial results for the year ended 31 December 2014. Available at: $\langle$ http:// www.sierrarutile.com/uploads/sierrarutilelimited2014annualreportandaccountsfinal25032015.pdf>. (Accessed:7 April 2020).

SRL, (2014b) Sierra Rutile Ltd, Sierra Rutile produces rutile, ilmenite and zircon from the world's largest natural rutile deposits Available at: www.sierrarutile.com/uploads/22631 sierrarutilefinal.pdf> (Accessed: 7 April 2020)

SRL.(2018). Community Development Action Plan for Sierra Rutile Limited, Sierra Leone report March 2018. Online at: https://www.iluka.com/getmedia/ff7a11ad-1aba-479a-9332-6844e42d5085/srl-area-1community-development-action-plan-final-201803.aspx (Accessed April 2020)

SLEDAT.(2020). Sierra Leone Economic Data Analytics Tool.A Report. Available at: www.edat.dsti.gov.sl. Accessed on March, 2020.

SLEITI, (2018). Sierra Leone Extractive Industries Transparency Initiative Ministry Of Mines And Mineral Resources Sleiti 2015, Report February 2018.

SLEITI, (2017).Sierra Leone Extractive Industries Transparency Initiative (SLEITI, 2015) Annual Progress Report. www.sleiti.gov.sl.

SLEITI, (2016). Sierra Leone Extractive Industries Transparency Initiative (SLEITI, 2015) Annual Progress Report. www.sleiti.gov.sl

SLEITI, (2015). Sierra Leone Extractive Industries Transparency Initiative (SLEITI, 2015) Annual Progress Report. www.sleiti.gov.sl.

Statistics Sierra Leone (2017). Report on the 2016 and 2017 real gross national domestic product (RGDP) figures as 2006 prices, national account unit Stats SL. Online at: https:/www.statistics.sl/images/ StatisticsSL/Documents/gdp/2017_gdp_analysis.pdf.

Statistics Sierra Leone and World Bank (2014). Sierra Leone 2014 Labor Force Survey Report, September 22 , 2015.

Statistics Sierra Leone. (2017). Consumer Price Index (CPI) March, 2017: PRESS RELEASE. Available fromhttps://www.statistics.sl/wp content/uploads/2017/05/cpi_press_release_march_2017.pdf

Swindell, K. (1975). Mining Workers in Sierra Leone: Their Stability and Marital Status. African Affairs, 74(295), 180-190. Retrieved March 10, 2020, from www.jstor.org/stable/721181temid=7

UNEP, (2010) United Nations Environment Programme, "Sierra Leone: Environment, Conflict and Peace building Assessment, Technical Report."Geneva: UNEP. Accessed on December 2, 2014. http://post conflict.unep.ch/publications/Sierra_Leone.pdf

Citation: ShiKui Dong, (2020)" The Untold Benefits of Mineral Mining in Developing Countries: A Case Study of Sierra Leone ", International Journal of Mining Science (IJMS), 6(2), pp. 41-51. DOI: http://doi. org/10.20431/2454-9460.0602004

Copyright: ( 2020 ShiKui Dong, This is an open-access article distributed under the terms of the Creative Commons Attribution License, which permits unrestricted use, distribution, and reproduction in any medium, provided the original author and source are credited. 